\title{
A kínai fejlesztő állam kihívásai
}

A tanulmány elsősorban két kérdésre keres választ. 1. Vajon nevezhető-e Kína fejlesztő államnak, illik-e rá a Japán, de még inkább a Dél-Korea és Tajvan által fémjelzett modell, illetve tekinthetö-e a kínai gazdasági csoda a fejlesztő állam újabb sikerének, vagy inkább a véletlenek összjátéka, és a páratlanul gyors növekedés teszi csak hasonlatossá az említett gazdaságokhoz? 2. Milyen tényezők befolyásolhatják Kína dinamikus gazdasági növekedésének folytatódását, és milyenek a kilátásai azon problémák leküzdésére, amelyekkel a reformfolyamat elindulása után negyven évvel szembe kell néznie. Az írás megmutatja, hogy bár több tekintetben is van különbségek a többi kelet-ázsiai gazdasághoz képest, az elmúlt két évtized kínai fejlődési pályája jól leírható a fejlesztő állam fogalmával. Igaz, a jelenlegi folyamatok fényében a kínai fejlesztő állam jövője nem tünik túlságosan biztatónak, mivel már most olyan tényezők hátráltatják a további dinamikus fejlődést, amelyek Tajvan vagy Dél-Korea esetében csak fejlődésük későbbi szakaszában jelentkeztek, és amelyek leküzdésére Kína aktuális politikai és gazdasági viszonyai nem kínálnak hathatós megoldást.

Journal of Economic Literature (JEL) kód: O17, P16, P30.

Az 1960-as évektől kibontakozó kelet-ázsiai gazdasági „csoda” ámulatba ejtette mind a szakmabelieket, mind a széles közvéleményt. Japán, majd később Tajvan és Dél-Korea látványos fejlődése hamarosan egy új fogalom megszületéséhez vezetett: a fejlesztő államéhoz. Egyre többen kezdték megkérdőjelezni azokat az alapelveket, amelyeket a fóáramú közgazdaságtan képviselői a gyors növekedés elérése és a szegénységből való kitörés érdekében a fejlődő országok számára javasoltak. A kelet-ázsiai sikergazdaságok példája nyilvánvalóvá tette, hogy az állam hathatós beavatkozása, egyes piacok szigorú védelme és az exportágazatok (vállalatok) szisztematikus támogatása egyaránt kulcsfontosságú a felzárkózáshoz vezető úton, és nem elégséges csakis a piacra bízni a folyamatokat. Japán, valamint a japán modellt számos tekintetben követő Tajvan és Dél-Korea fejlödési pályái és intézményi

\footnotetext{
Székely-Doby András a Budapesti Corvinus Egyetem Összehasonlító és Intézményi Gazdaságtan Tanszékének docense (e-mail: andras.szekely-doby@uni-corvinus.hu). A kézirat első változata 2017. április 2-án érkezett szerkesztőségünkbe. DOI: http://dx.doi.org/10.18414/KSZ.2017.6.630
} 
megoldásai olyan sok hasonlóságot mutattak, hogy a fejlesztő állam hamarosan a gazdasági felzárkózás általános példájává vált. ${ }^{1}$ A fejlődő világ számos országa merített ihletet e sikerekből, és kezdte alkalmazni a fejlesztő állam egyes vonásait. Miután azonban az 1980-as évek végétől a növekedés lassulni kezdett, és egyre nyilvánvalóbbakká váltak a strukturális problémák, a fejlesztő államba vetett hit megingott, az 1998-as délkelet-ázsiai pénzügyi válság súlyos következményei pedig végleg eloszlatták a modellt övező hajdani dicsfényt.

Az ezredforduló környékén megsokasodott azoknak a müveknek a száma, amelyek a fejlesztő állam hanyatlásáról, bukásáról vagy végéről szólnak (például: Pang [2000], Beeson [2004] vagy Williams [2014]), és ismét kezdtek teret nyerni a kelet-ázsiai országok gazdasági sikereit relativizáló, ezzel együtt pedig a piac mindenhatóságát hirdető munkák. E müvek többsége (sokat építve korábbi - szintén kritikus - írásokra, mint Balassa [1988], Krueger [1990] vagy Krugman [1994]) mindenekelőtt az említett gazdaságok piackonform megoldásait hangsúlyozták, miközben az állam gazdasági szerepvállalásának jelentőségéről csak mellékesen szóltak, és a válságjelenségek leküzdésére a fỏáramú receptet javasolták. Az állam erőteljes beavatkozása a gazdasági folyamatokba azonban ezekben a gazdaságokban a válság után sem tünt el teljesen, sőt sokan úgy vélik (mint például Amsden-Chu [2003], Wong [2004] vagy Fields [2012]), hogy a fejlesztö állam lényegi elemei megmaradtak, miközben sikeresen alkalmazkodott az új kihívásokhoz. Mi sem mutatja ezt jobban, mint Dél-Korea és Tajvan gyors növekedése az ezredforduló után, és felemelkedésük a legfejlettebb országok csoportjába.

A délkelet-ázsiai pénzügyi válság a régió más országainak a fejlődését sem akasztotta meg teljesen, legtöbbjük hamar túljutott a nehézségeken, és folytatódott a gyors növekedés. Különösen izgalmas ebböl a szempontból Kína esete, mely az 1978-as reform és nyitás politikáját követően, példátlan gazdasági növekedést produkálva, a világ legdinamikusabban fejlődő országává vált. A tervutasításos gazdasági rendszer leépítésével párhuzamosan egyre több piacgazdaságra jellemző intézményi megoldás terjedt el az országban, egyre nagyobb szerep jutott a magánvállalkozásoknak, és az ország világgazdasági integrációja is egyre mélyebbé vált, nem utolsósorban hatalmasra duzzadó áruexportja révén. A gyors ütemü fejlödést látva, Kína teljesítményét mind többen kezdték Kelet-Âzsia feltörekvő gazdaságaiéhoz - elsősorban a Tajvanéhoz és Dél-Koreáéhoz hasonlítani, és mind többször lehetett hallani arról, hogy valójában Kína nem tesz mást, mint adaptálja a fejlesztő állam jellegzetességeit sajátos viszonyaira.

Tanulmányunkban elsősorban két kérdésre keresünk választ. Egyrészt, szeretnénk megvizsgálni, hogy vajon nevezhetjük-e Kínát fejlesztő államnak, illik-e rá a Japán, de még inkább a Dél-Korea és Tajvan által fémjelzett modell, és tekinthetjük-e a kínai gazdasági csodát a fejlesztő állam újabb sikerének, vagy inkább a véletlenek összjátéka és a páratlanul gyors növekedés teszi csak hasonlatossá ezekhez az országokhoz. Másrészt, arra is kíváncsiak vagyunk, hogy milyen tényezők befolyásolhatják Kína dinamikus gazdasági növekedésének folytatódását, és milyenek a kilátásai

\footnotetext{
${ }^{1}$ Lásd erről többek között Johnson [1982], Wade [1988] és [1990], White [1988], Amsden [1989] és Evans [1995], de érdekes az eredmények föáramú közgazdaságtani értékelése is, mint például Balassa [1991]-ben.
} 
azon problémák leküzdésére, amelyekkel a reformfolyamat elindulása után negyven évvel szembe kell néznie. Elemzésünk révén kiderül, hogy bár több tekintetben is mutatkoznak különbségek a többi kelet-ázsiai gazdasághoz képest, az elmúlt két évtized kínai fejlődési pályájára jól alkalmazható a fejlesztő állam megközelítése. Azzal is szembesülünk ugyanakkor, hogy a jelenlegi folyamatok fényében a kínai fejlesztö állam jövője nem tünik túlságosan biztatónak, mivel már most olyan tényezők hátráltatják a további dinamikus fejlődést, amelyek Tajvan vagy Dél-Korea esetében csak fejlődésük későbbi szakaszában jelentkeztek, és amelyek leküzdésére Kína aktuális politikai és gazdasági viszonyai nem kínálnak hathatós megoldást.

A tanulmány első részében összefoglaljuk a kelet-ázsiai fejlesztő állam legfontosabb jellegzetességeit, és kiemeljük azokat az elemeket, amelyek alapján eldönthető, hogy illik-e Kínára a fejlesztő állam modellje. Ezt követően összehasonlítjuk Kína fejlődését a kelet-ázsiai „kis tigrisek” korábbi időszakbeli teljesítményével, és megvizsgáljuk, mennyiben támasztják alá a statisztikai adatok a fejlesztő állam fogalmának Kínára való alkalmazhatóságát. Majd a kínai fejlesztő állam kialakulásának folyamatát kísérjük végig, és amellett érvelünk, hogy fejlesztő államról Kína esetében az 1990-es évek közepe óta beszélhetünk. Az utolsó részben sorra vesszük azokat a kihívásokat, amelyek leküzdése sorsdöntő lehet az ország jövőbeli növekedési kilátásai szempontjából, és rámutatunk azokra a nehézségekre, amelyek megkérdőjelezhetik (vagy esetleg teljesen el is lehetetleníthetik) Kína kétségkívül hatalmas növekedési képességének kiaknázását. A tanulmányt rövid összefoglalással zárjuk.

\section{A fejlesztő állam fogalma}

Japán sikerei az 1970-es évektől kezdődően új fejezetet nyitottak nemcsak a gazdaságtörténetben, de a fejlődés kérdésével foglalkozó közgazdaságtani szakirodalomban is. Chalmers Johnson úttörő mủve (Johnson [1982]) nyomán megszületett a fejlesztő állam fogalma, amely eredetileg a japán csoda intézményi hátterét volt hivatva bemutatni. A japán modell egyes elemeit később fokozatosan átvették a kelet-ázsiai feltörekvő gazdaságok (Tajvan, Dél-Korea, Szingapúr és Hongkong) is, bizonyítva, hogy a gyors gazdasági felzárkózás és modernizáció korántsem lehetetlen vállalkozás. A fejlesztő állam jellegzetességeit és nemzeti változatait bemutató strukturalista - vagy más néven heterodox ${ }^{2}$ - közgazdaságtani iskola legkiválóbb képviselöi (Wade [1988], [1990], White [1988], Amsden [1989], [2001], Evans [1995], Woo-Cumings [1999] vagy Knight [2014]) ${ }^{3}$ a gazdasági fejlődés feltételeit és lehetőségeit más szemszögből vizsgálták, mint a hagyományos neoklasszikus közgazdaságtan. Elemzéseikben ötvözték többek között a közgazdaságtani, történeti institucionalista, szociológiai és politológiai megközelítéseket, és ezen irányzatok együttes alkalmazásával kíséreltek meg magyarázatot adni a kelet-ázsiai változásokra.

\footnotetext{
${ }^{2}$ Gyakran használatos még a revizionista vagy államközpontú megközelítés is (Ricz [2015] 9. o.).

${ }^{3}$ Magyar nyelven kiváló összefoglalást nyújt a témáról többek között Benczes [2002], [2009], Csáki [2009] és Ricz [2015].
} 
Jóllehet a fejlesztő állam fogalmán az említett szerzők nem teljesen ugyanazt értették, máshol húzták meg a határokat, és más tényezőket emeltek ki, figyelemre méltó közeledés mutatkozik az általuk hangsúlyozott legfőbb vonások tekintetében. A következökben összegyüjtjük a fejlesztő állam legfontosabb jellegzetességeit, szem előtt tartva azonban azt, hogy célunk elsősorban nem a lehető legalaposabb fogalmi tisztázás vagy a szakirodalom teljes körü bemutatása, hanem annak vizsgálata, hogy a fejlesztő állam főbb elemei hogyan illeszkednek (illetve illeszkednek-e egyáltalán) Kína elmúlt évtizedekbeli gyors növekedéséhez, intézményi átalakulásához és alkalmazott politikáihoz.

A fejlesztő állam fogalma kapcsán Johnson [1982] elsősorban Japán felemelkedéséröl írt. A gyors növekedés mögött meghúzódó intézményi tényezők közül kiemelte a kis méretű, olcsó, de kiváló minőségü bürokráciát, amely a kezdeményezésre és a hatékony megoldások alkalmazására elegendő teret engedő politikai rendszer keretei között müködik. Fontosnak ítélte azt is, hogy az állam mindenekelött piackonform módon avatkozik be a gazdaságba, és folyamatosan tökéletesíti e beavatkozási formákat. A japán modell utolsó elemeként egy olyan csúcsszervet említett - a MITI-t, a külkereskedelmi és ipari minisztériumot -, amely megfelelően képes összehangolni a folyamatokat (Johnson [1982] 315-319. o.). Johnson nyomdokain haladva Tajvanról szóló könyvében Wade [1990] már fejlesztő államról ír, amelynek első számú célja a gazdasági növekedés. A fejlesztő állam elkötelezett a magántulajdon és a piaci mechanizmus iránt, és beavatkozásait alárendeli ezen alapelveknek. Ugyanakkor nem paszszív, éppen ellenkezőleg: aktívan tereli a piacot, mégpedig olyan eszközökkel, amelyeket a gazdasági bürokrácia krémje alakít ki. Hangsúlyozza emellett, hogy az állam folyamatosan konzultál és együttmüködik a magánszférával, és amíg a bürokraták irányítanak (rule), addig a politikusok uralkodnak (reign).

A dél-koreai fejlesztő államot Alice $\mathrm{H}$. Amsden a későn iparosodó országok speciális eseteként értelmezi (Amsden [1989], [2001]). Az állam - a későn jövők gyakorlatának megfelelően - támogatások formájában avatkozik be a gazdaságba, hogy a relatívárakat torzítva ösztönözze a befektetéseket. Ám (Japánhoz és Tajvanhoz hasonlóan) az állam itt nemcsak támogat, hanem egyben fegyelmezi is a támogatottak körét, méghozzá oly módon, hogy teljesítménykövetelményeket fogalmaz meg velük szemben, és be is tartatja ezeket. A jó teljesítményeket (mint például a kiemelkedő exportmutatók) további engedélyek kiadásával jutalmazza, míg a gyenge eredményeket felmutató vállalatok esetében büntetéseket alkalmaz (megvon bizonyos jogosultságokat). A támogatások nagy részét az állam a kivételezett helyzetben lévő vállalatcsoportokhoz (chaebolokhoz) juttatja, amelyeket az állami tulajdonú bankrendszer, az ipari engedélyezési politika és a tőkeáramlások korlátozása segítségével ellenőriz. Az állam a szelektív elkülönítés elvét alkalmazza (egyes piacokat megnyit a külföldi verseny elött, míg másokat nem), miközben segíti a nemzeti vállalatok gyors növekedését.

Boltho-Weber [2009] a fogalom kapcsán kifejezetten Kínát vizsgálja. A szerzőpáros amellett érvel, hogy a jelenlegi Kínára igenis alkalmazható a kelet-ázsiai fejlesztő állam fogalma (pontosabban a felvázolt fejlödési modell). Az alapvető tulajdonságok közé sorolja a beruházások, a feldolgozóipari szektor és a külső versenyképesség gyors növelésének folyamatos igényét, a versenygazdaság erényeibe 
vetett erős hitet, a stabil makrogazdasági környezet megteremtését, valamint olyan - a növekedés szempontjából - kedvező társadalmi előfeltételek biztosítását, mint a széles körü oktatás, a viszonylagos jövedelemegyenlőség, a kompetens bürokrácia vagy az autoriter kormányzat.

Knight [2014] jóval általánosabb kereteket fogalmaz meg a fejlesztő állammal kapcsolatban. Véleménye szerint csupán két kritériumnak kell teljesülnie ahhoz, hogy fejlesztő államról beszélhessünk: a kormányzatnak legfontosabb célként a gazdasági növekedést kell kitűznie, és olyan intézményi kereteket és ösztönző struktúrákat kell alkalmaznia, amelyek hozzásegíthetik fö céljának eléréséhez. Megközelítésében szándékosan nem foglalkozik a különböző országokban tapasztalható eltérő iparosítási stratégiákkal és szakpolitikákkal, ehelyett - sokkal tágabban értelmezve a fejlesztő állam fogalmát - inkább csak a leglényegesebb vonásokra összpontosít. Mindezek alapján Knight is amellett érvel, hogy Kína egyértelmüen fejlesztö államnak tekinthető.

Tanulmányunkban a fejlesztő államot elsősorban olyan eszköznek tekintjük, amely a későn jövők esetében segíthet hozzájárulni a fejlett országok csoportjához való gyors felzárkózáshoz. ${ }^{4}$ Jóllehet megközelítésünk erősen kapcsolódik az állam által vezérelt gazdasági rendszer fogalmához, amely mindenekelött az angolszász - piac által vezérelt - modell ellenpólusaként értelmezhető (lásd Bara-Szabó [2000], illetve Szabó [2007]), az utolérés és a felzárkózás hangsúlyozása, továbbá adott fejlettségbeli és történelmi viszonyok feltételezése (különösen a kelet-ázsiai sajátosságok tekintetében) meg is különbözteti attól. Ennek megfelelöen nem foglalkozunk azzal a kérdéssel, hogy vajon miképpen alakul át a fejlesztő állam a sikeres felzárkózás után, milyen válságjelenségek mutatkoznak benne, vagy fenntartható-e egyáltalán. Célunk ehelyett inkább az, hogy megvizsgáljuk, alkalmazható-e a fejlesztő állam fogalma Kínára, illetve a felzárkózás során milyen feszültségekkel és kihívásokkal kell szembenéznie az országnak. Mivel elemzésünk a kelet-ázsiai térségre vonatkozik, fejlesztő államon a továbbiakban a fejlesztő állam kelet-ázsiai változatait értjük.

A fejlesztő állam fogalmának definíciójába elsősorban azokat a jellegzetességeket értjük bele, amelyek hangsúlyosan megjelentek mind Japán, mind Dél-Korea, mind Tajvan esetében, és amelyek jól jellemezték az említett gazdaságok sajátos - nyugati mintáktól eltérö - fejlödési útját. Elemzésünkben nem térünk ki sem Hongkong, sem Szingapúr példájára, mivel - Alice Amsden szavaival - e városállamok közül „egyik sem arról a mezőgazdasági vagy nyersanyagbázisról kezdte meg fejlődését, amely általában az ipari átalakulás kiindulópontját jelenti” (Amsden [1989] 4. o.).

A fejlesztő állam meghatározó tulajdonságai között a következőket említhetjük. 1. A fejlesztő állam első és legfontosabb meghatározó tulajdonsága (amely szinte minden szerzőnél megjelenik) a gyors gazdasági növekedés mint abszolút prioritás. Ez a cél ugyan sokszor más (elsősorban politikai) kényszer hatására válik döntő fontosságúvá, a gyors fejlődés időszakában azonban egy ilyen hatás mindig másodlagos, és nem befolyásolja a vezetés növekedés iránti elkötelezettségét.

\footnotetext{
${ }^{4} \mathrm{Ez}$ a megközelítés sok hasonlóságot mutat Gerschenkron munkáival (lásd például Gerschenkron [1984/1951] 35-67. o.).
} 
2. A kompetens, jelentős autonómiával és valós jogkörökkel rendelkező bürokrácia a növekedést elősegítö intézményi változások és politikák kialakításának fö letéteményese.

3. A piaci folyamatok iránti elkötelezettség, amely többek között szükséges ahhoz is, hogy megvalósulhasson az állami beavatkozások és támogatások feltételekhez, számon kérhető eredményekhez való kötése. A piaci versenyre való hagyatkozás természetesen nem mindig, mindenhol és minden körülmények között valósul meg, de ahol fontos a teljesítmények valós értékelése (mint például az exporttermékek versenyképessége esetén), ott ennek a mércének a használata elengedhetetlen.

4. A megfelelő külső környezet biztosítása, mégpedig a makrogazdasági stabilitás, az emberi erőforrás képzése, a jövedelmi egyenlőtlenségek alacsony szinten tartása és a társadalmi-politikai rend fenntartása tekintetében.

A továbbiakban Kína kapcsán a fejlesztő állam fogalmának ezt a négy tulajdonságát vizsgáljuk.

\section{A kínai növekedés összehasonlító szemszögből}

A fejlesztő állam gazdasági növekedéshez való hozzájárulása Kelet-Ázsiában tagadhatatlan tény, ugyanakkor rendkívül nehéz megítélni ennek pontos mértékét. Amíg ugyanis a gyors növekedés időszaka jól behatárolható, addig igen nehéz megbecsülni a gazdaságokban az időszak kezdetéig felhalmozódó rejtett potenciált. Mire gondolunk? A gazdasági fejlődés általános értelemben véve nemcsak az aktuális intézmények és gazdaságpolitika függvénye, hanem erősen befolyásolják a múlt meghatározó intézményei és történelmi eseményei is. Éppen ezért a fejlesztő állam megjelenésekor az adott ország vagy gazdaság történelmi és intézményi öröksége - az útfüggöség - legalább olyan fontos szerepet játszhat az elkövetkező évtizedek teljesítményében, mint magának a fejlesztő államnak a tevékenysége. Nem következtethetünk tehát minden további nélkül a gazdaságpolitika sikerességére pusztán a jó gazdasági eredményekből.

Minél több szempontot veszünk azonban figyelembe, és minél távolabbi múltba tekintünk vissza, annál nehezebbé válik nemcsak az eredmények értékelése, de az elemzési időszak meghatározása is. Honnan számítsuk például a kínai fejlesztő állam történetét? Az 1950-es évek elejétől, amikor Kína hihetetlen ütemü iparosításba kezdett? Vagy a reform és nyitás időszakának kezdetétől, 1978-tól? Vagy még későbbtől, amikor az 1990-es évek közepén végbement a nagyfokú újraközpontosítás? Ugyanezeket a kérdéseket - természetesen más időszakokra vonatkozóan - feltehetjük Japánnal, Koreával és Tajvannal kapcsolatban is. Nevezhetjük-e fejlesztő államnak az 1890-es évektől gyors iparosításba kezdő japán kormányt? Hogyan értékeljük a két világháború közötti gyors fejlödést Koreában és Tajvanon a japán megszállás idején? Ezek a kérdések nem akadémikusak: a rájuk adott válaszok nagymértékben befolyásolják azt, hogy egy stratégiát mennyiben tekinthetünk valóban sikeresnek, illetve mennyiben tükrözi a gazdaságok teljesítménye a múltban felhalmozott potenciál jobb kiaknázását. 
Szerencsére a fejlesztő államra adott korábbi definíciónk segít eligazodni az alternatív nézetek között. Kína esetében például (hasonlóan a többi kommunista országhoz) nem szokták az 1978 előtti időszakot a fejlesztő államhoz kötni (Johnson [1982]), ${ }^{5}$ többek között azért sem, mert a vezetés mind a piaccal, mind a külkereskedelemmel szemben igen ellenséges volt, miközben a verseny, a hatékonyság és a valós teljesítmények értékelése egyáltalán nem valósult meg. Arra a kérdésre, hogy 1978 után beszélhetünk-e kínai fejlesztő államról, vagy csak az 1990-es évek közepe után (vagy még akkor sem), később fogunk választ adni.

Jóllehet Japán esetében az intézményi és technológiai folytonosság a két világháború közti és a második világháború utáni időszak között nyilvánvaló, a fejlesztő állam ideáltipikus sajátosságai csak az 1950-es éveket követően váltak uralkodóvá. Nem véletlen, hogy a fejlesztő állam fogalma is csak ezután jelent meg az országgal kapcsolatban. Ugyanez az érvelés Tajvan és Dél-Korea kapcsán is elmondható, kiegészítve azzal, hogy a gyarmati státus vége, a polgárháború pusztításai és a szuverenitás visszanyerése gyökeres szakítást jelentettek a múlttal, új kezdet ígéretét hozva el mindkét gazdaság számára. Ez még akkor is így van, ha fejlődési pályájukat alapvetően befolyásolták a korábbi évtizedek intézményei és gazdaságfejlesztési stratégiái (Wade [1988] és Kohli [1994]). Mindezek alapján - egyszersmind követve BolthoWeber [2009], valamint Fields [2012] szakaszolását - Japán esetében a fejlesztő állam kibontakozásának kezdetét az 1950-es évekre, Tajvannal kapcsolatban az 1960-as évek elejére, Dél-Korea esetében pedig az 1960-as évek közepére tehetjük.

A Boltho-Weber szerzőpáros cikkéhez hasonlóan először mi is az egy főre jutó GDP alakulását vizsgáljuk vásárlóerő-paritáson (Boltho-Weber [2009] 282. o.). Az 1. ábra tanúsága szerint a növekedési ütemek a különböző gazdaságok gyors fejlődési szakaszaiban közel azonosak voltak (ezt a vonalak párhuzamossága jelzi a logaritmikus skálán), ám a kezdeti és az elért fejlettségi szintek igencsak eltértek.

A megfelelő összehasonlítási alap érdekében a gazdaságok vásárlóerö-paritáson számított egy före jutó GDP-jét az adott év egyesült államokbeli egy före jutó GDP-jéhez mérjük. A 2. ábrán jól látható, hogy Japánban például a vizsgált időszak kezdetén (1950-ben) az egy főre jutó GDP a megfelelő egyesült államokbeli érték 20 százalékát tette ki, s 1980-ra elérte a 70 százalékát. Kína ennek a referenciaértéknek a 20 százalékát csak 2008-ra, a vizsgált időszak legvége felé érte el, de fejlődése így is rendkívül dinamikus volt, hiszen 1980-ban még csak kevesebb mint 6 százalékon állt. Tajvan és Dél-Korea a két nagy között helyezkedik el: az 1965-ös 10 és 15 százalék közötti szintről 1995-re megközelítették (illetve Tajvan meg is haladta) az egyesült államokbeli egy före jutó GDP felét.

Használhatjuk-e azonban a fejlesztő állam fogalmát Kína esetében, ha az egy före jutó GDP értékei ilyen alacsonyak? Természetesen igen, mi azonban amellett fogunk érvelni, hogy csupán az 1990-es évek közepétől kezdődik az az időszak, amikor már valóban érdemesnek tünik Kína esetében fejlesztő államról beszélni. Ennek okait a későbbiekben részletezzük. Ha most így nézzük az adatokat, Kína

\footnotetext{
${ }^{5}$ Johnson [1982] két külön kategóriát használt a szocialista országok, illetve a fejlesztő állam tekintetében: a tervideologikus, valamint a tervracionális modellt (lásd még Bassa [2009] 161. o.).
} 


\section{1. ábra}

A különböző gazdaságok egy főre jutó GDP-je a jelzett időszakokban (dollár vásárlóerő-paritáson, logaritmikus skála)

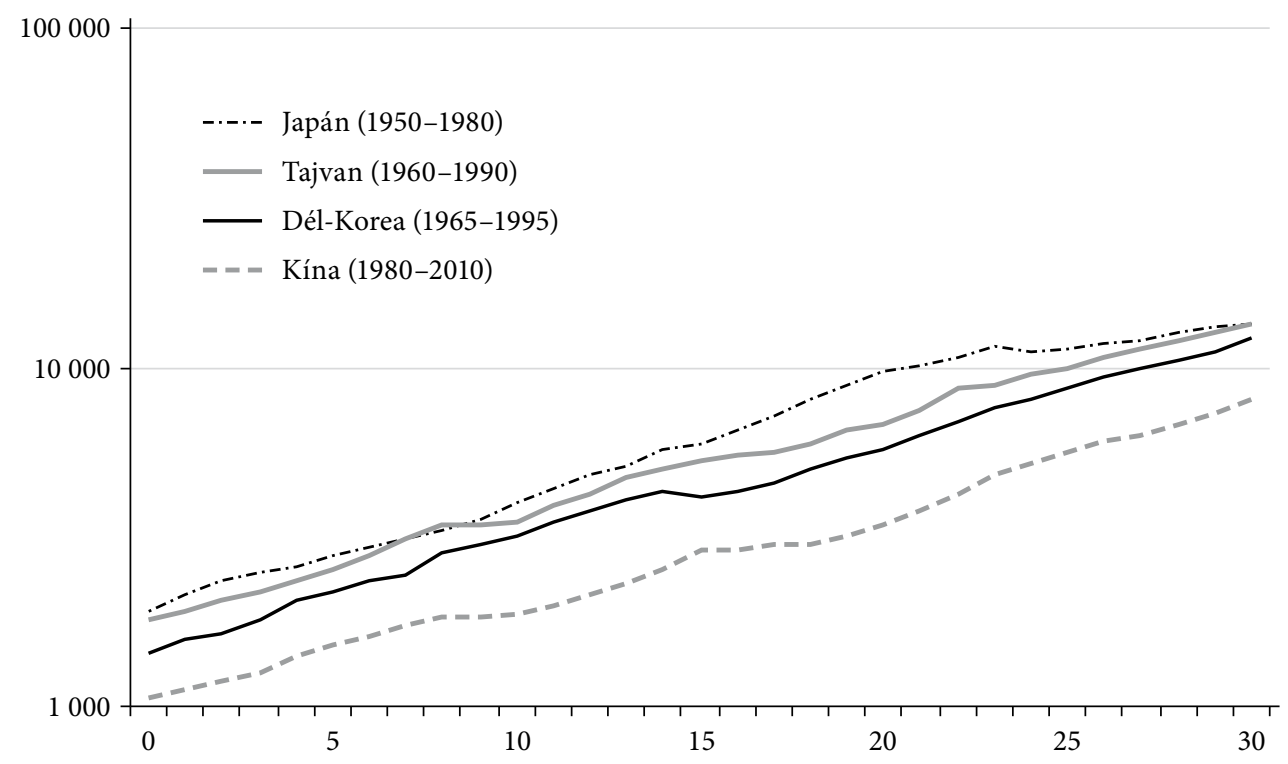

Adatok forrása: Maddison-Project.

\section{2. ábra}

A különböző országok egy főre jutó GDP-je (dollár vásárlóerő-paritáson) a jelzett időszakokban az Egyesült Államok megfelelő időszakaihoz viszonyítva (százalék)

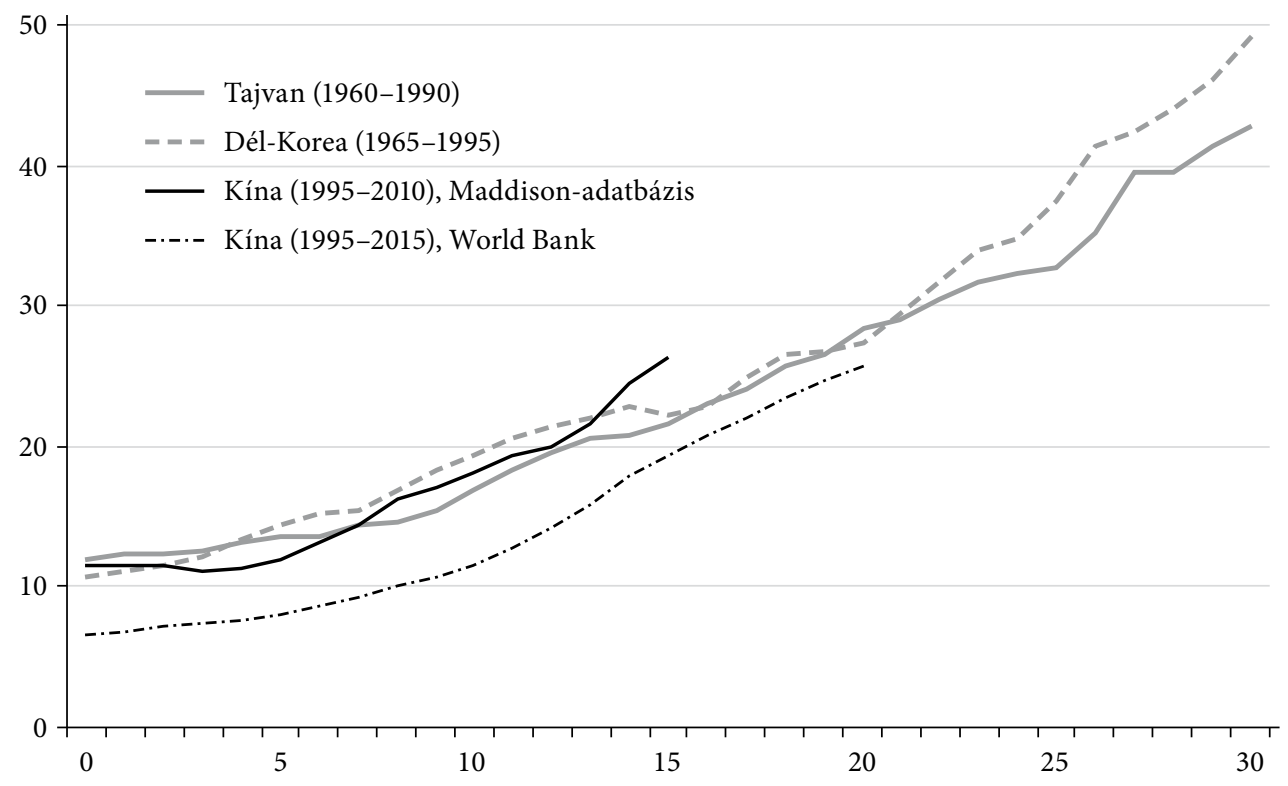

Adatok forrása: Maddison-Project, World Bank - World Development Indicators. 
3. ábra

Különböző gazdaságok GDP-arányos állótőke-beruházásai a jelzett időszakokban (százalék)

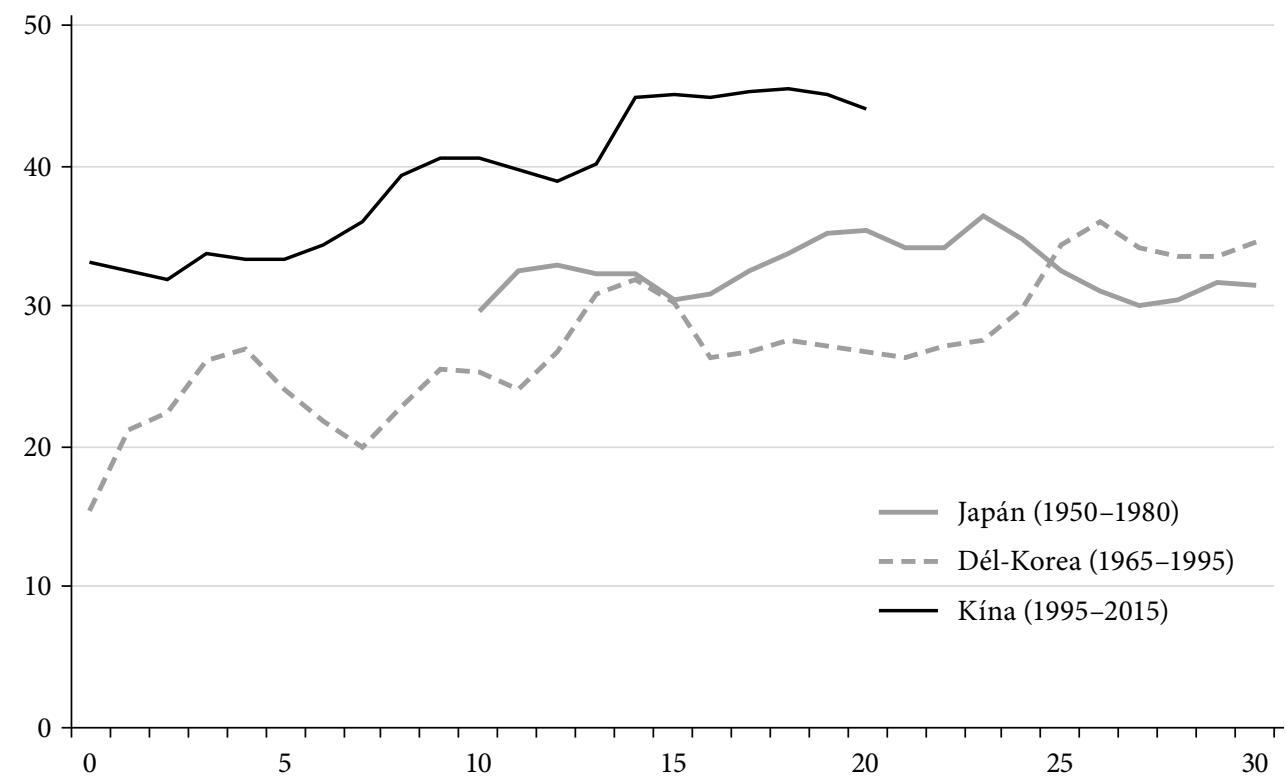

Adatok forrása: World Bank - World Development Indicators.

ma a fejlesztő állam által fémjelzett növekedési időszak közepén tart, és teljesítménye annak ellenére jól összemérhető Tajvan és Dél-Korea azonos időszakbeli teljesítményeivel, hogy jelenleg abszolút értékben még igen messze áll tőlük. Tajvan és Dél-Korea eredményei rendkívüliek: sikeresen csatlakoztak a fejlett országok szűk csoportjához (2016-ban mindkét gazdaság egy főre jutó GDP-je meghaladta az amerikai szint 65 százalékát). Kína eközben csupán 26 százalékig jutott, ${ }^{6}$ ezt a szintet Japán 1956-ban, Tajvan 1979-ben, Dél-Korea pedig 1983-ban érte el. ${ }^{7}$ Kína kapcsán egyébként két különbözö becslést is mutat a 2. ábra. A 2010-ig elérhető Maddison-adatbázis lényegesen magasabb értékeket mutat, mint a Világbanké, jól érzékeltetve, hogy mennyire bizonytalanok ezek az adatok.

Az idősorok tehát leginkább arra mutatnak, hogy Kína fejlődési trendje akkor áll a legközelebb a kis tigrisek pályáihoz, ha a vizsgált időszak kezdőpontjának az 1990-es évek közepét választjuk. A szakaszhatár kijelölésében azonban - természetesen nemcsak statisztikai adatok vezetnek bennünket, hanem azok a nagyon fontos intézményi változások is, amelyekre ebben az időszakban került sor. Az ekkoriban végbement újra-központosítást követően a kínai állam már egyre inkább egy feltörekvő országra hasonlított, ahol reális célkitűzés lehetett (és lehet ma is) a fejlett országokhoz való, belátható időn belüli felzárkózás.

\footnotetext{
${ }^{6} \mathrm{Az}$ adatok forrása itt és a fejezet további részében: World Bank - World Development Indicators.

${ }^{7}$ Pontosan ezek miatt az adatok miatt választottuk az összehasonlítás alapjául dolgozatunkban elsősorban Tajvant és Dél-Koreát.
} 
Mielőtt azonban túlzottan optimisták lennénk Kína jövőbeli teljesítményét illetően, érdemes egy pillantást vetnünk a beruházások alakulására. Ha a felzárkózás folyamatát 1995-től vizsgáljuk, igen jelentős különbséget láthatunk egyfelől Kína, másfelől Japán és Dél-Korea beruházási rátáit illetően. Míg utóbbiak esetében a GDP-arányos állótőke-beruházások mértéke még a fellendülés időszakának vége felé is jócskán elmaradt a 40 százaléktól (azóta pedig a 20 és 30 százalék közötti szintre állt be), addig Kína már a vizsgált időszak első évtizedében elérte a 40 százalékot, és azóta is magasan felette áll (3. ábra). Valójában egyetlen más országban sem volt ilyen magas a beruházások aránya, és igen valószínűtlennek tűnik, hogy e beruházások mindegyike jövedelmező lenne. A magas beruházási ráta fenntarthatatlansága gazdasági lassuláshoz és az ezzel együtt járó politikai elégedetlenséghez vezethet. A nagyrészt állami megrendelésekből és infrastrukturális projektekből álló beruházások tehát csak ideig-óráig lesznek képesek fenntartani a már most lassuló kínai gazdaság dinamikus növekedését.

\section{A kínai fejlesztő állam kialakulása}

Ebben a részben amellett érvelünk, hogy Kína esetében a fejlesztő állam megjelenése az 1990-es évek közepén bevezetett átfogó reformprogram utánra datálható. Mind a fejlesztő állam általunk fontosnak ítélt alapvető sajátosságai, mind a kínai átalakulás politikai-gazdaságtani jellegzetességei ugyanis arra mutatnak, hogy az 1980-as évek fejleményei még nem egyeztethetők össze a fejlesztő állam fogalmával, helyette sokkal inkább a szocialista rendszer megreformálásáról, nemegyszer pedig spontán piaci erők térhódításáról szólnak, amelyek gyakran éppen a vezetés elképzelései ellenére valósultak meg.

Az 1978 után elinduló kínai reformfolyamat első szakaszában ${ }^{8}$ a változások lényege Pareto-hatékonyságukban volt megragadható (Knight [2014]). A Kínai Kommunista Párt (a továbbiakban KKP) elsősorban olyan változásokat engedélyezett, amelyek amellett, hogy nem kerültek konfliktusba a szocialista tervgazdaság alapvető struktúráival (mindenekelött az állami nagyvállalatok kiterjedt rendszerével), nagymértékben hozzájárultak a gazdasági teljesítmény javulásához. A legfontosabb lépések többsége - például a háztartás-felelösségi rendszer bevezetésével fémjelzett mezőgazdasági reform vagy a vidék újraiparosításában döntő szerepet játszó vidéki vállalatok (Township and Village Enterprises, TVE-k) gyors térnyerése nem központi utasítások eredménye volt, csak a spontán változások utólagos jóváhagyásával vált hivatalos politikává.

A termelőeszközök magántulajdona és a piaci formák azonban továbbra is csak másodlagos szerepet játszhattak a szocialista gazdaság müködésében, nyilvánvalóvá téve, hogy ebben az időszakban valódi kapitalista átalakulásról még nem beszélhetünk. Ehelyett inkább a reformszocializmus és a „reform vesztesek nélkül” kifejezésekkel lehet leírni a rendszer lényegét. Ezen az sem változtat, hogy ekkoriban nyíltak meg az első különleges gazdasági övezetek (Special Economic Zones), amelyekben

\footnotetext{
${ }^{8}$ A szakirodalomban leginkább elfogadott értelmezés szerint ez körülbelül 1993-ig tartott (lásd például Naughton [2007]).
} 
- hasonlóan más kelet- és délkelet-ázsiai országok példáihoz - a külföldi partnerek vegyes vállalati formában, ${ }^{9}$ területenkívüliséget élvezve, az olcsó helyi munkaerőt kihasználva termeltek, méghozzá általában kizárólag exportra.

Az átalakulásnak ez a szakasza a tervgazdaság fokozatos lebontásával és megszüntetésével, a kettős árrendszer, valamint a kettős vágányú gazdaság - a tervutasítások és a piac párhuzamos müködése - bevezetésével mindenekelőtt a kapitalista struktúrák fokozatos (elsősorban spontán) térnyerését hozta, miközben a kínai állam legtöbbször csak követő módon (Benczes [2009] 46. o.), gyakran a változások utólagos engedélyezésével járult hozzá a folyamatok alakulásához (Naughton [2007]). Mi sem bizonyítja jobban, hogy ebben az időben a kínai gazdaság még távol állt a bevezetőben jellemzett fejlesztő államtól, mint az, hogy az állami nagyvállalatok fokozatosan tért vesztettek tartósan alacsony hatékonyságuk és a fokozódó verseny hatására, illetve a központi költségvetés forrásai gyorsan elapadtak, ami végül az 1994-es átfogó adó- és költségvetési reformhoz vezetett.

Amellett tehát, hogy a vezetők körében megjelent a gyors gazdasági növekedés mint fontos (jóllehet nem egyedüli és leglényegesebb) cél, hiányoztak az ehhez kapcsolódó eszközök (például az erős központi irányítás vagy a viszonylagosan autonóm, technokrata beállítottságú bürokrácia), valamint a piaci folyamatok iránti elkötelezettség. Ráadásul az időszak vége felé megingott a makrogazdasági stabilitás, egyre nagyobb méreteket öltött a korrupció is, ami egyértelmủen hozzájárult a társadalmi elégedetlenség fokozódásához és az 1989-es véres események kirobbanásához.

Nem véletlen, hogy a KKP 1994-ben új stratégia és átfogó reformok bevezetése mellett döntött, amivel egyrészt meg kívánt felelni a gazdaság további átalakítása iránti egyre sürgetőbb igénynek, másrészt ettől várta saját politikai érdekeinek előmozdítását is. Az átfogó adó- és költségvetési reform révén a források a helyi és tartományi szintekről ismét a központba áramlottak, nagymértékben felértékelve a központi vezetés (ezzel együtt pedig a központi bürokrácia) szerepét. Ugyancsak a források feletti ellenőrzés racionalizálását szolgálta a vállalati reform elindítása is, amelynek keretében az állam a „Ragadd meg a nagyot, és engedd el a kicsit!” (Zhua da fang xiao) jelszónak megfelelően megtartotta az ellenőrzést a stratégiailag fontos vagy kivételezett helyzetükből adódóan jövedelmezö nagyvállalatok felett, miközben a többit vagy eladta, vagy hagyta csödbe menni (Naughton [2007]). A vállalatok irányítása is változásokon ment keresztül: egyre nagyobb szerepet kapott a profitorientált gondolkodásmód. Az újraközpontosítással egyidejüleg megkezdődött néhány kiválasztott nagyvállalat nemzeti bajnokká fejlesztése is, egyaránt célba véve a külföldi, de még inkább az egyre bővülő belső piacot. A magántulajdon és a piac dominánssá válásával, valamint ezek hivatalos, pártvezetés általi elfogadásával Kína kapitalista országgá vált. ${ }^{10}$

Az átalakulás azonban nemcsak a gazdasági rendszer alapvető jellegét érintette, hanem a vezetés stratégiáját is. A KKP saját, jól felfogott érdekétől vezérelve, a gazdasági növekedés legföbb propagálójává vált. Amíg ugyanis dinamikus a gazdasági

\footnotetext{
${ }^{9}$ Amelyekben a kínai állam kezdetben többségi tulajdonnal rendelkezett.

${ }^{10}$ A rendszerátmenet kritériumait lásd Kornai [2007], Kína esetére való alkalmazását pedig Székely-Doby [2014].
} 
bővülés, jók az eredmények, a párt vezető szerepe nem kérdőjelezhető meg. Hasonló politikai szempontok más kelet-ázsiai fejlesztő államok esetében is hozzájárultak a növekedés iránti elkötelezettségéhez: Tajvanon a Kínai Népköztársasággal, Dél-Koreában a Koreai Népi Demokratikus Köztársasággal szembeni önvédelem, általánosságban pedig a kommunizmus elleni kérlelhetetlen harc nyomán, jelentős segítséget kapva ugyanakkor az Egyesült Államoktól. A növekedés fö céllá való előléptetése - hasonlóan más fejlesztő államokhoz (Kim [2011]) - Kínában is mindenekelött politikai kérdés volt. Akárhogy is, az 1990-es évek közepétől kezdve a gazdasági növekedés minden más célt felülírt Kínában. ${ }^{11} \mathrm{~A}$ cél elérését segítette a bürokrácia fokozatos professzionalizálódása, valamint a politikai szféra lassú intézményesülése is, különösen pedig az a fejlemény, hogy a jutalmak és a büntetések alapja a vezetők körében egyre inkább az általuk irányított egység növekedéshez való hozzájárulása lett (Knight [2014]). A kapitalista átalakulással együtt a piac és a verseny megítélése is változott, és hivatalosan is egyre nagyobb szerepet szántak ezen új intézményeknek a gyors növekedés elérésében. A fejlesztő állam kritériumai közül csupán a 4. jellemző (a külső körülmények biztosítása) esetében mutatható ki komolyabb hiányosság. A gazdasági és politikai stabilitás végig megmaradt ugyan, a környezeti károk és a fokozódó egyenlőtlenségek azonban nagy kihívások elé állították a kínai vezetőket. Ezekről a problémákról a következő részben szólunk.

Bármennyire fontos eredmény volt is a kapitalista átalakulás, az átmenet korántsem tekinthető teljesnek, sőt mind a mai napig messze nem az. Ez azonban nem a központi vezetés erötlensége vagy a szocialista rendszer egyes intézményeinek szívóssága miatt alakult így. Éppen ellenkezőleg: a reformfolyamat félbehagyása az átmeneti intézmények legfőbb haszonélvezőinek ('igy a központi vezetésnek is) alapvetö létérdeke volt és maradt. A pénzügyi rendszer liberalizációja vagy a stratégiailag fontos állami nagyvállalatok valódi privatizációja ugyanis elzárná a legfontosabb járadékforrásokat, és olyannyira meggyengítené a pártállam gazdaság feletti ellenőrzését, hogy magának a rendszernek a bukását is elörevetítené. Nyilvánvalóan ez az oka annak, hogy a KKP - sorozatos ígéretei ellenére - mindeddig nem szánta rá magát e lépések megtételére, és egyelöre semmi jel nem mutat arra, hogy ez valaha is bekövetkezne (Shambaugh [2016]). A részleges reformegyensúly (Hellman [1998]) - vagy más néven tranzíciós csapda (Pei [2006]) - ugyanakkor olyan struktúrákat hívott életre, melyek nagyon hasonlítanak a kelet-ázsiai fejlesztő államoknak a fejlődésük hasonló szakaszában alkalmazott megoldásaihoz. Az erős központi vezetés ellenőrzése alatt tartja a pénzügyi rendszert, amelynek segítségével irányítani, jutalmazni és büntetni képes mind az állami, mind a magánvállalatokat, miközben kiemelt támogatásokban részesítheti a politikailag és stratégiailag fontos szereplőket. A makrogazdasági stabilitás mellett - nem utolsósorban a hathatós állami beavatkozásoknak köszönhetően - Kína exportteljesítménye is páratlanul erőssé vált. A vezetés növekedés iránti elkötelezettsége (amely a párt legitimációjának fenntartását és erősítését hivatott szolgálni) végül tehát olyan intézményeket és ösztönzöket hívott életre, amelyek a kínai gazdaságot

\footnotetext{
${ }^{11}$ Leszámítva természetesen a KKP hatalmi monopóliumának megőrzését mint mindenekfeletti parancsot.
} 
fokozatosan fejlesztő állammá alakították át. Az alapvető hasonlóságok mellett a kínai fejlesztő állam számos tekintetben különbözik is kelet-ázsiai elődjeitöl, és a különbségek - mint látni fogjuk - kétségeket ébresztenek esetleges jövőbeli sikereit illetően.

\section{Válságjelenségek és a kínai fejlesztő állam kilátásai}

Kína 1978 utáni gazdasági teljesítménye vitathatatlanul lélegzetelállító. Immár közel négy évtizede képes stabil és gyors növekedésre, aminek következtében szegény, fejlődő országból közepesen fejlett országgá vált. Kérdés azonban, hogyan folytatódik a felzárkózás, képes lehet-e az elkövetkezendő évtizedekben Tajvan és Dél-Korea példáját követve megközelíteni a fejlett országokat, elérheti-e például egy-két évtizeden belül az Egyesült Államok vásárlóerő-paritáson számított egy före jutó jövedelmének felét (mint ahogy az az 1990-es évek közepére sikerült Tajvannak és Dél-Koreának), vagy csökkenő versenyelőnyei miatt végleg beragad a „közepes jövedelem csapdájába” (Shambaugh [2016], Woo [2012]). A következőkben rámutatunk azokra a baljós jelekre és veszélyekre, amelyek megkülönböztetik a kínai fejlesztö állam jelenlegi sajátosságait a többi kelet-ázsiai fejlesztő állam hasonló időszakban megmutatkozó jellemzőitől, és amelyek komoly kérdőjeleket vetnek föl a jövőbeli gyors növekedés fenntarthatóságát illetően. Annál is időszerübb ez a kérdés, mivel Hszi Csin-ping 2012-es hatalomra kerülése óta komoly politikai fordulat ment végbe a kínai vezetésben, fokozódott a represszió, megkezdődtek a szüken vett pártvezetésen belül a korrupciós vádak álarca mögé bújtatott leszámolások, és tovább nőtt a központi vezetésnek, elsősorban pedig magának a fötitkárnak az ereje (Pei [2016a]). E fejlemények ugyan látszólag nem állnak ellentétben a fejlesztő állam fogalmával, a jövőbeli gyors növekedésre leselkedő legnagyobb veszélyt azonban mégis a jelenlegi rendszer megkövesedése, bebetonozódása jelenti, ami feltételezi a már meglévő járadékforrások még intenzívebb kiaknázását, a kizsákmányoló gazdasági intézmények (Acemoglu-Robinson [2013]) további erősödését, valamint a korrupció és a haveri kapitalizmus (Pei [2016b]) térnyerését.

Kína elsősorban három tényező miatt különbözik a többi kelet-ázsiai fejlesztő államtól, és elsősorban ezek a tényezők kérdőjelezik meg korábbi dinamikus növekedésének fenntarthatóságát. Egyrészt méretéből adódóan azok a fontos jellegzetességek, amelyeknek nagy jelentőségük volt más országok esetében, mint például az erőteljes exportorientáció vagy a hatékony, autonóm és központosított bürokrácia, Kína esetében kevésbé erősen jelennek meg. Másrészt, jóllehet Kína iparosítása már a szocialista érában jelentős méreteket öltött, és nem csak az 1980-as évektől kezdőden indult útjára, technológiája, ipari struktúrája, szervezeti és intézményi megoldásai elmaradottak voltak, és igen kevéssé hatékonyak. A szocialista örökség így nemhogy nem könnyítette meg a felzárkózást, hanem épp ellenkezőleg: megnehezítette. Az átalakítás, a hagyományos struktúra lebontása és az új felépítése ugyanis rendkívül nehéz feladat, ráadásul a régi (értsd: szocialista) reflexek folyamatosan akadályozzák is a változásokat. Végül a gyors fejlődés keretfeltételeinek megroppanása, mindenekelött a környezetszennyezés, valamint a hatalmas regionális és jövedelmi egyenlötlenségek kiéleződése rendkívül kedvezőtlenül hatnak a növekedésre. 
Kína a 2010-es évek közepére vásárlóerő-paritáson számított GDP tekintetében megelőzte az Egyesült Államokat, és ezzel a világ legnagyobb gazdaságává vált. Exportteljesítménye alapján szintén világelső, ráadásul több mint 2000 milliárd dolláros exportjával az ország méretéhez képest igen nyitottnak számít (az export/ GDP arány meghaladja a 22 százalékot). Nettó exportja azonban kevésbé számottevő, „,mindössze” a GDP 3,5 százalékát teszi ki, ami ugyan közel 400 milliárd dollár, a növekedéshez való hozzájárulása azonban csekély. Egy ekkora ország esetében - főleg hosszabb távon, a felzárkózáshoz vezető út későbbi szakaszában - kizárólag vagy elsősorban az exportra mint a növekedés fö motorjára hagyatkozni a fogyatkozó versenyelőnyök miatt nem is lehetséges. A kínai vezetés már régóta tisztában van ezzel, és hangoztatja is, hogy célja a fogyasztásalapú növekedés megteremtése, ám a tények egyelöre mást mutatnak. Az elmúlt évtizedben a növekedés motorjává nem a fogyasztási kiadások, hanem a beruházások léptek elö, amelyeknek jelentős része az állam által finanszírozott projektekből tevődik össze. 2010 óta az állótőkeberuházások aránya a GDP-ben meghaladja a 45 százalékot, ami a modern világgazdaságban példátlanul magas értéknek számít, és minden bizonnyal fenntarthatatlannak bizonyul majd a jövőben. ${ }^{12}$

A legnagyobb problémát azonban a belső piacon megvalósuló, hatalmas mennyiségü beruházással kapcsolatban a valós piaci verseny szelekciós mechanizmusainak hiánya jelenti. A beruházások ugyanis - ellentétben a tajvani vagy koreai példával elsősorban nem a hatékonyságot és a nemzetközi versenyképességet ösztönzik, nem teljesítményfüggők (mint az export), hanem mindenekelött politikai célokat szolgálnak, mégpedig a mesterséges monopolhelyzetben lévő állami nagyvállalatok (és persze vezetőik) járadékainak (Ho [2013], Lu [2000]), ezzel együtt pedig a KKP forrásainak és hatalmának fenntartását (Shambaugh [2016]). Amíg tehát más kelet-ázsiai fejlesztö államok a méretgazdaságossági elönyök megteremtését a nemzeti bajnokok felfejlesztésével együtt a világgazdasági verseny kemény viszonyai közt érték el, a hatalmas, állami tulajdonú kínai vállalatok támogatása a valós teljesitmények figyelmen kívül hagyásával, rövid távú politikai szempontok szerint történik.

Ugyancsak az ország méretéből és diverzifikáltságából adódó probléma az irányítás viszonylagos decentralizáltsága (Breslin [2012] 45. o.). Xu [2011] kifejezésével élve: ez egy „területileg decentralizált autoriter rendszer” (1076. o.), amely túlságosan nagy teret enged a korrupciónak és a járadékvadászatnak, valamint a követhetetlen pénzügyi megoldások elterjedésének, ezek pedig az eladósodottság kezelhetetlen méreteit vonhatják maguk után. A központi vezetés az 1990-es évek reformjaival sokat tett ugyan az irányítás és az ellenőrzés visszaszerzése érdekében, mégsem tudta - az ország mérete miatt nem is lehetett erre képes - teljesen megakadályozni a partikuláris érdekek érvényesülését.

Dél-Koreában egészen az 1990-es évekig a legfelső politikai vezetés és a chaebolok irányítóinak összefonódása és egymásrautaltsága közös érdekké tette a gyors növekedést: „egymás túszai voltak” (Kang [2004] 7. o.). Az alsóbb szinteken ezzel szemben igen kemény autoriter módszerek alkalmazásával vették elejét a korrupciónak, miközben a vállalatcsoportok közötti oligopolisztikus verseny ösztönözte a fejlődést és a hatékonyság

\footnotetext{
${ }^{12}$ Adatok forrása: World Bank - World Development Indicators.
} 
növelését (Kim [2011] 11. o.). Tajvanon ugyanekkor a nehézipart ellenőrzésük alatt tartó állami vezetők, valamint a munkaerö-igényes ágazatokban nemzetközi sikereket elérö helyi (elsősorban kis méretű, családi) vállalkozások egymásrautaltsága, „szövetsége” akadályozta meg a járadékvadászat túlzott elburjánzását (Fields [2012] 56. o.).

Kínában azonban más a helyzet. A részleges reformegyensúly és a rosszul definiált tulajdonjogok központi és helyi szinten lehetővé tették a politikai vezetés és a nagyvállalati oligarchák összejátszását, ami végül kiterjedt korrupciós háló kialakulásához vezetett, sokkal komolyabb károkat okozva, mint ha a korrupció csak egyedi esetek formájában jelentkezett volna (Pei [2016b]). Számos veszély leselkedik az állami ellenőrzés alatt tartott pénzügyi rendszerre is. Elég csak a hatalmasra nött árnyékbankrendszerre gondolni, vagy arra, hogy az összes hitelmennyiség GDP-hez mért aránya 2012-re elérte a 200 százalékot (Wong [2013] 10. o.), belátható, hogy a rendszer ellenálló képessége aligha teszi lehetővé a gyors gazdasági növekedés fenntartását (Woo [2012]). Az a tény tehát, hogy Kína a felzárkózás folyamatában még korántsem ért el olyan eredményeket, mint Tajvan vagy Dél-Korea (nem is beszélve Japánról), miközben az országot átható, a gazdasági eredményeket alapjaiban veszélyeztetö korrupció az egész társadalmat átszövi, pénzügyi rendszerének gyengeségei pedig már most nyilvánvalókká váltak, egy erős és magabiztos nagyhatalom képe helyett inkább egy sebezhető és kedvezőtlen kilátásokkal szembenézni kénytelen óriást vetít elénk.

A kínai fejlesztő állam másik fő problémája a szocialista örökség. Itt nem elsősorban a gazdaság szerkezetében fellelhető olyan anomáliákra gondolunk, mint például a pénzügyi szektor fejletlensége vagy az állami vállalatok kivételezett helyzete és kevéssé hatékony működése, hanem a politikai elit és alapjában véve az egész rendszer túlélöképességére. Ez azért problematikus, mert a politikai változások hiánya fokozatosan bebetonozza azokat a kedvezötlen müködési mechanizmusokat, amelyek végül teljesen alá is áshatják a felzárkózáshoz vezető utat. A kínai kommunista rezsim rugalmassága (Nathan [2003]) és a hatalom megtartása érdekében mutatott elkötelezettsége - legalábbis az elkövetkező évekre vonatkozóan - nagyon valószínütlenné teszi az olyan jellegü változások bekövetkeztét, amelyek az 1980-as évektől kezdődően fokozatosan átalakították, demokratizálták és megtisztították mind Tajvant, mind Dél-Koreát, lehetővé téve új fejlődési irányok és új stratégiák kijelölését és megvalósítását.

Végül szólnunk kell azokról a keretfeltételekben mutatkozó kedvezőtlen fejleményekről is, amelyek Kína jövőbeli fejlödésének gátjaivá válhatnak. Az egyik ilyen probléma a környezetrombolás, ami Kína esetében - a gyors ipari fejlődéssel párhuzamosan - korábban még nem látott méreteket öltött, és egyre nagyobb kihívást jelent az országnak mind gazdasági, mind társadalmi, mind politikai szempontból. Különösen igaz ez, ha figyelembe vesszük, hogy az elégedetlenség és a sokasodó tüntetések ${ }^{13}$ leggyakoribb kiváltó oka az emberek környezetének és életminőségének gyors romlása. Ugyancsak fokozza a társadalmi elégedetlenséget a jövedelmi egyenlőtlenségek hatalmas méretűvé duzzadása. Ellentétben a környezetszennyezéssel, a jelentős jövedelmi

\footnotetext{
${ }^{13}$ A környezetszennyezéssel kapcsolatos tömegtüntetések száma 1996 és 2014 között évente 29 százalékkal nőtt, 2014-ben már több száz hasonlóról érkezett beszámoló, és az is megállapítható, hogy a környezeti problémák a tömegmegmozdulások leggyakoribb kiváltó okai között szerepelnek (CECC[2015] 209. o.).
} 
különbségek nem voltak jellemzők más kelet-ázsiai fejlesztő államokra. ${ }^{14}$ Épp ellenkezőleg: a gyors gazdasági növekedés mind Tajvan, mind Dél-Korea esetében mérsékelt jövedelmi egyenlőtlenség mellett ment végbe, nem véletlen, hogy a folyamatot a megosztott növekedés névvel illették (Benczes [2000] 431. o.), utalva arra a tényre, hogy a gyors fejlődés igen jelentős költségei megoszlottak a társadalmi szereplők között. Kínában nem ez a helyzet: az egyenlőtlenségek folya matosan nőnek, ${ }^{15}$ ami a kiszolgáltatott csoportok és a leszakadó rétegek helyzetének romlásához, a feszültségek növekedéséhez vezet. Paradox módon a környezetszennyezés közvetve, az elégedetlenség manifesztálódása révén hozzájárulhatna a demokratizálódáshoz, ennek jelei azonban egyelőre nem látszódnak. Sokkal valószínübb, hogy a KKP-nek sikerül megtalálnia azt az egyensúlyt a növekedés parancsa és a környezeti károk enyhítése között, amely a legkevésbé veszélyezteti hatalmát, ám az is nagyon valószínűnek tünik, hogy e politika eredményeként a növekedés jóval lassabb lesz, mint a korábbi évtizedekben.

\section{Összefoglalás}

Tanulmányunkban amellett érveltünk, hogy a Japánban, majd később Tajvanon és Dél-Koreában kialakuló kelet-ázsiai fejlesztő állam modellje jól alkalmazható Kína elmúlt évtizedekben tapasztalható fejlődési jellegzetességeire. A gazdasági növekedés középpontba helyezése, a fokozatosan professzionalizálódó bürokrácia térnyerése (amely egyszersmind megfelelö autonómiát is élvez), a piaci folyamatok dominánssá válása és vezetők általi elismerése, bizonyos területeken az előmenetel és a jutalmazás piaci teljesítmény alapján történő értékelése (különösen az export terén), végül pedig a stabil külső környezet biztosítása az állam részéről mind arra mutat, hogy Kína mára kétségtelenül egyfajta fejlesztő állammá vált. A korábbi reformszocialista rendszer átalakulása és a fejlesztő állam megjelenése egyaránt az 1990-es évek közepére tehető, amikorra a magántulajdon és a piac dominánssá válása (a kapitalista rendszer megjelenése) mellett az átfogó adó- és költségvetési reform egy új stratégia alapjainak lehetőségét teremtette meg. Az új irányvonal jóval jelentősebb - és tudatosabb - szerepet szánt az államnak a gazdasági fejlődésben, s a stratégiai szektorok (köztük a pénzügyi szféra) feletti irányítás megtartása révén sikerült is ennek megfelelő intézményrendszert kialakítania.

A kínai fejlesztő állam azonban számos nehézséggel küzd, amelyek közül némelyik nyíltan, némelyik pedig rejtett módon veszélyezteti a dinamikus növekedés fenntarthatóságát. Különösen annak fényében fenyegetők e tényezők, hogy a kínai felzárkózás a fejlett országokhoz egyelöre legfeljebb félúton jár, miközben annak idején, Tajvan és Dél-Korea felzárkózásakor a nehézségek és a rendszer strukturális problémái csak jóval később jelentkeztek. A beruházások mértékének fenntarthatatlansága, a nagy állami vállalatok - a verseny és a piac szelektáló mechanizmusainak figyelembevétele

\footnotetext{
${ }^{14}$ Jelentős mértékủ környezetszennyezés volt tapasztalható Tajvanon is az 1980 -as évektől kezdődően.

${ }^{15}$ A Gini-index Japán esetében 2011-ben 37,9 (1993-ban még csak 24,9), Dél-Koreában 2014-ben 30,2, Tajvanon pedig ugyanekkor 33,6 volt, Kínában 2014-re 46,9-re emelkedett (CIA - Gini-index).
} 
nélküli - politikai alapú támogatása, a pénzügyi rendszer gyengeségéből és megreformálatlanságából fakadó egyensúlytalanságok, az óriási méreteket öltő, immáron szervezett formában megjelenő korrupció, a fokozódó egyenlőtlenségek és a példátlan környezetszennyezés ${ }^{16}$ egyértelmüvé teszik, hogy a korábbi évtizedek gyors növekedési üteme alapvető változások nélkül nem tartható fenn.

A változásoknak azonban - amelyek egyrészt a félbemaradt vagy még el sem kezdődött reformok véghezvitelét (különösen az állami nagyvállalatok és a pénzügyi rendszer átalakítását), másrészt a politikai rendszer fokozatos demokratizálódását jelentenék - még a körvonalai sem látszódnak. A Kínai Kommunista Párt ellenálló képessége és a hatalom megőrzése érdekében tett rendkívül hatékony lépései nagyon valószínütlenné teszik, hogy a folya matok alakulásában (legyenek azok gazdaságiak vagy politikaiak) belátható időn belül alapvető változások álljanak be. Márpedig ezek hiányában a kínai fejlesztő állam hatékonysága - különösen az elözőkben említett akadályok miatt - egyre gyengébb lesz, a fejlett országokhoz való gyors felzárkózás reménye pedig egyre távolabbivá válik. Nem állítjuk, hogy a cél elérése lehetetlen lenne, de a rendszer müködéséből adódó súlyos nehézségek alapjaiban kérdőjelezik meg az országban rejlő lehetőségek minél teljesebb kiaknázását és az esetleges jövőbeli gazdasági sikereket.

Kína nagy utat járt be a reformok kezdete óta, gazdasági eredményei lenyügözők. Négy évtizednyi dinamikus növekedés után közepesen fejlett országgá, vásárlóerő-paritáson számolva pedig a világ legnagyobb gazdaságává vált, százmilliókat emelve ki közben a szegénység és kilátástalanság csapdájából. Szocialista tervutasításos rendszerét megreformálva sikerült kapitalista alapokon nyugvó modernizációt végrehajtania, ezzel együtt pedig kialakítania egy kelet-ázsiai mintájú fejlesztő állam intézményi kereteit. Eredményei mellett azonban számos tényező (mint például az ország nagy mérete, decentralizált jellege, a szocialista múlt öröksége, a kiterjedt korrupció vagy a politikai vezetés hatalmának megingathatatlansága) mutat arra, hogy a korábbi dinamikus növekedés lassulni fog, és az ország akár be is ragadhat a közepes jövedelmü országok csapdájába. Minthogy a kiutat innen csak olyan alapvető változások jelenthetnék, amelyekre jelen körülmények között nem számíthatunk, meg kell barátkoznunk azzal a gondolattal, hogy fokozatosan elérkezik a Kínai Kommunista Párt vezetése alatt mintegy két évtizede müködő fejlesztő állam alkonya.

\section{Hivatkozások}

Acemoglu, D.-Robinson, J. A. [2013]: Miért buknak el nemzetek? A hatalom, a jólét és a szegénység eredete. HVG Kiadói Rt., Budapest.

Amsden, A. [1989]: Asia's Next Giant. South Korea and Late Industrialization. Oxford University Press, New York.

Amsden, A. [2001]: The Rise of 'the Rest': Challenges to the West from Late-Industrializing Economies. Oxford University Press, Oxford, https://doi.org/10.1093/0195139690.001.0001.

\footnotetext{
${ }^{16}$ A helyzet súlyosságáról kiváló összefoglalást nyújt a Világbank konferenciakiadványa: The World Bank [2007].
} 
Amsden, A.-Chu, W. [2003]: Beyond Late Development. Taiwan's Upgrading Policies. MIT Press, Cambridge.

Balassa, B. [1988]: The Lessons of East Asian Development: An Overview. Economic Development and Cultural Change, Vol. 36. No. 3. 273-290. o. https://doi.org/10.1086/edcc.36. s3.1566546.

Balassa, B. [1991]: Economic Policies in the Pacific Area Developing Countries. MacMillan Press, London, https://doi.org/10.1007/978-1-349-12045-1.

BARA Zoltán-Szabó Katalin (szerk.) [2000]: Gazdasági rendszerek, országok és intézmények. Aula Kiadó, Budapest.

BAssa Zoltán [2009]: A fejlesztő állam és a pénzügyi szektor modernizációja. Megjelent: Csáki (szerk.) [2009] 161-200. o.

Beeson, M. [2004]: The Rise and Fall (?) of the Developmental State: The Vicissitudes and Implications of East Asian Interventionism. Megjelent: Low, L. (szerk.): Developmental States: Relevancy, Redundancy or Re-configuration. Nova Science Publisher, New York., 29-40. o.

Benczes István [2000]: A Távol-Kelet gazdasági rendszerei. Megjelent: Bara-Szabó (szerk.) [2000] 425-464. o.

Benczes István [2002]: A fejlesztő állam válsága Ázsiában. Külgazdaság, 46. évf. 5. sz. 23-40. o.

Benczes István [2009]: Erős állam - gyenge társadalom. A fejlesztő állam intézményi perspektívában. Megjelent: Csáki (szerk.) [2009] 35-64. o.

Boltho, A.-Weber, M. [2009]: Did China follow the East Asian development model? The European Journal of Comparative Economics, Vol. 6. No. 2. 267-286. o. https://doi. org/10.1017/CBO9781139962858.009.

BresLIN, S. [2012]: Government-Industry Relations in China: A Review of the Art of the State. Megjelent: Walter, A.-Zhang, X. (szerk.): East Asian Capitalism: Diversity, Continuity, and Change. Oxford University Press, Oxford, 29-45. o. https://doi.org/10.1093/acprof: oso/9780199643097.003.0002.

CECC [2015]: Congressional-Executive Commission on China, Annual Report, 2015, Washington, D. C., https://www.cecc.gov/sites/chinacommission.house.gov/files/2015\%20Annual\%20 Report.pdf.

CIA - GINI-INDEX: https://www.cia.gov/library/publications/the-world-factbook/fields/2172.html.

CsÁki György (szerk.) [2009]: A látható kéz. A fejlesztő állam a globalizációban. Napvilág Kiadó, Budapest.

Evans, P. [1995]: Embedded Autonomy: States and Industrial Transformation. Princeton University Press, Princeton.

Fields, K. J. [2012]: Not of a Piece: Developmental States, Industrial Policy, and Evolving Patterns of Capitalism in Japan, Korea, and Taiwan. Megjelent: Walter, A.-Zhang, X. (szerk.): East Asian Capitalism: Diversity, Continuity, and Change. Oxford University Press, Oxford, 46-67. o. https://doi.org/10.1093/acprof:oso/9780199643097.003.0003.

Gerschenkron, A. [1984/1951]: Gazdasági elmaradottság történelmi távlatból. Gondolat Kiadó, Budapest.

Hellman, J. S. [1998]: Winners Take All: The Politics of Partial Reform in Postcommunist Transitions. World Politics, Vol. 50. No. 2. 203-234. o. https://doi.org/10.1017/ S0043887100008091.

Ho, W. C. [2013]: The New 'Comprador Class': The re-emergence of bureaucratic capitalists in post-Deng China. Journal of Contemporary China, Vol. 22. No. 83. 812-827. o. https:// doi.org/101080/10670564.2013.782128. 
Johnson, C. [1982]: MITI and the Japanese Miracle: The Growth of Industrial Policy, 19251975. Stanford University Press, Stanford, https://doi.org/10.1086/ahr/88.1.158.

KANG, D. C. [2004]: Crony Capitalism: Corruption and Development in South Korea and the Phillippines. Cambridge University Press, Cambridge.

KIM, B. K. [2011]: Introduction: The Case for Political History. Megjelent: Kim, B. K-Vogel, E. F. (szerk.): The Park Chung Hee Era: The Transformation of South Korea. Harvard University Press, Cambridge, 1-31. o.

Knight, J. B. [2014]: China as a Developmental State. The World Economy, Vol. 37. No. 10. 1335-1347. o. https://doi.org/10.1111/twec.12215.

KoHLI, A. [1994]: Where do high growth political economies come from? The Japanese lineage of Korea's 'developmental state'. World Development, Vol. 22. No. 9. 1269-1293. o. https://doi.org/10.1016/0305-750X(94)90004-3.

KoRnaI János [2007]: Szocializmus, kapitalizmus, demokrácia és rendszerváltás. Akadémiai Kiadó, Budapest.

Krueger, A. [1990]: Asian Trade and Growth Lessons. American Economic Review, Vol. 80. No. 2. 108-112. o.

Krugman, P. [1994]: The Myth of Asia's Miracle. Foreign Affairs, Vol. 73. No. 6. 62-78. o. http://dx.doi.org/10.2307/20046929.

Lu, X. [2000]: Booty Socialism, Bureau-Preneurs, and the State in Transition: Organizational Corruption in China. Comparative Politics, Vol. 32. No. 3. 273-294. o. https://doi. org/10.2307/422367.

MAdDison-Project: http://www.ggdc.net/maddison/maddison-project/home.htm.

Nathan, A. [2003]: Authoritarian Resilience. Journal of Democracy, Vol. 14 No. 1. 6-17. o. https://doi.org/10.1353/jod.2003.0019.

National Bureau of Statistics of China - China Statistical Yearbook [2016]: http:// www.stats.gov.cn/tjsj/ndsj/2016/indexeh.htm.

Naughton, B. [2007]: The Chinese Economy. Transitions and Growth. MIT Press, Cambridge.

PAnG, E. [2000]: The Financial Crisis of 1997-98 and the End of the Asian Developmental State. Contemporary Southeast Asia, Vol. 22. No. 3. 570-593. o. https://doi.org/10.1355/ cs22_3g.

PeI, M. [2006]: China's Trapped Transition: The Limits of Developmental Autocracy. Harvard University Press, Cambridge.

PeI, M. [2016a]: The Beginning of the End. The Washington Quarterly, Vol. 39. No. 3. 131142. o. https://doi.org/10.1080/0163660X.2016.1232640.

PEI, M. [2016b]: China's Crony Capitalism: The Dynamics of Regime Decay. Harvard University Press, Cambridge.

RICZ JUDIT [2015]: Fejlesztő állam - egy letűnt világ nyomában (?). MTA KRTK Világgazdasági Intézet Mühelytanulmányok, 108. http://mek.oszk.hu/16000/16029/16029.pdf.

Shambaugh, D. [2016]: Contemplating China’s Future. The Washington Quarterly, Vol. 39. No. 3. 121-130. o. https://doi.org/10.1007/s11366-017-9491-x.

Szabó Katalin (szerk.) [2007]: Összehasonlító gazdaságtan. Aula Kiadó, Budapest.

SzÉKELY-Doby AndRÁs [2014]: A kínai átalakulás politikai-gazdaságtani logikája. Közgazdasági szemle, 59. évf. 12. sz. 1397-1415. o.

WADE, R. [1988]: State Intervention in 'Outward-looking' Development: Neoclassical Theory and Taiwanese Practice. Megjelent: White, G. (szerk.) [1988], https://doi.org/10.1007/9781-349-19195-6_2. 
WADE, R. [1990]: Governing the Market: Economic Theory and the role of Government in East Asian Industrialization. Princeton University Press, Princeton, https://doi.org/10. 2307/1964105.

White, G. (szerk.) [1988]: Developmental States in East-Asia. The Macmillan Press, London, https://doi.org/10.1007/978-1-349-19195-6.

Williams, M. (szerk.) [2014]: The end of the developmental state. Routledge, New York.

Wong, C. M. [2013]: Beijing seeks to pop ballooning NPLs. Asiamoney, szeptember, 10-13. o.

Wong, J. [2004]: The Adaptive Developmental State in East Asia. Journal of East Asian Studies, Vol. 4. No. 3. 345-362. o. https://doi.org/10.2307/23417946.

Woo, W. T. [2012]: China meets the middle-income trap: The large potholes in the road to catching-up. Journal of Chinese Economic and Business Studies, Vol. 10. No. 4. 313-336. o. https://doi.org/10.2139/ssrn.2177074.

Woo-Cumings, M. (szerk.) [1999]: The Developmental State. Cornell University Press, New York.

WORLD BANK - WORLD DEvelopment IndicAToRs: http://databank.worldbank.org/data/ views/variableSelection/selectvariables.aspx?source=world-development-indicators.

World BAnk [2007]: Cost of Pollution in China: Economic Estimates of Physical Damages. The World Bank, Washington, D. C.

Xu, C. [2011]: The Fundamental Institutions of China's Reforms and Development. Journal of Economic Literature, Vol. 49. No. 4. 1076-1151. o. https://doi.org/10.2307/23071664. 